Jurnal Ilmiah Ibnu Sina, 5(2), Oktober 2020, 278-287

p-ISSN: 2502-647X; e-ISSN: 2503-1902

\title{
TINGKAT PENGETAHUAN APOTEKER KOMUNITAS MENGENAI PENGOBATAN ASMA
}

\author{
Amelia Lorensia ${ }^{*}$, Rifaatul Laila Mahmudah ${ }^{2}$, Leonardo Immanuel ${ }^{1}$ \\ ${ }^{1}$ Departement of Community and Clinical Pharmacy, Pharmacy Faculty, \\ University of Surabaya \\ ${ }^{2}$ Departement of Public Health, Stikes Majapahit \\ *Email: amelia.lorensia@gmail.com
}

Artikel diterima: 4 Mei 2020; Disetujui: 10 September 2020

DOI: https://doi.org/10.36387/jiis.v5i2.495

\begin{abstract}
ABSTRAK
Terapi asma yang optimal membutuhkan kerjasama antara pasien dan apoteker sebagai tenaga kesehatan. Melalui pelayanan kefarmasian, apoteker berperan memberikan edukasi dan pemantauan terapi asma. Namun tingkat pengetahuan apoteker akan menjadi kuci penting dalam pelaksanaannya. Penelitian ini bertujuan mengetahui tingkat pengetahuan pengobatan asma dari apoteker komunitas di Kota Surabaya Timur. Desain penelitian yang digunakan dalam penelitian ini adalah cross-sectional dan pengambilan data dilakukan melalui kuesioner dari penelitian sebelumnya. Tingkat pengetahuan meliputi 6 domain, yaitu domain terapi farmakologi, etiologi dan patofisiologi, faktor risiko, definisi, gejala, dan terapi non farmakologi. Subjek adalah apoteker yang melakukan praktek di apotek di Surabaya Timur. Pengambilan data dilakukan dengan mendatangi apotek satu per satu untuk menemui perwakilan apoteker dari setiap apotek. Wawancara dilakukan secara langsung dengan subjek penenelitian. Pada penelitian ini analisa data dilakukan deskriptif. Penelitian dilakukan mulai April-Juni 2019 dengan melibatkan 108 orang. Sebagian besar subjek memiliki tingkat pengetahuan asma yang sedang/standar $(37,96 \%)$ dan hanya Sebagian kecil yang memiliki tingkat pengetahuan yang tinggi $(27,77 \%)$. Domain paling tinggi adalah pada terapi non-farmakologi $(94,00)$ dan nilai terendah pada domain gejala $(43,00)$. Oleh karena itu, apoteker perlu meningkatkan pengetahuannya agar dapat membantu pasien asma mencapai pengobatan yang optimal.
\end{abstract}

Kata kunci: asma, apoteker, apotek, pengetahuan

\begin{abstract}
Optimal asthma therapy requires collaboration between patients and pharmacists as health-workers. Through pharmacy services, pharmacists have role of providing education and monitoring asthma therapy. But level of pharmacist's knowledge will be important in its implementation. This study studies the level of medical knowledge from the community in the city of East Surabaya. The research design used in this study was cross-sectional and data collection was carried out through questionnaires from previous studies. The level of knowledge includes 6 domains, namely domain of pharmacological therapy,
\end{abstract}


Jurnal Ilmiah Ibnu Sina, 5(2), Oktober 2020, 278-287

p-ISSN: 2502-647X; e-ISSN: 2503-1902

etiology and pathophysiology, risk factors, resolution, symptoms, and nonpharmacological therapy. The subject was pharmacist who practices at pharmacy in East Surabaya. Data was collected by visiting pharmacies one by one to invite pharmacists from each pharmacy. Interviews were conducted directly with research subjects. In this study descriptive data analysis was performed. The study was conducted from April to June 2019 with 108 people. Most subjects had moderate/ standard asthma knowledge (37.96\%) and only small proportion had high level of knowledge (27.77\%). The lowest domain was in nonpharmacological therapy (94.00) and the lowest value was in the question domain (43.00). Therefore, pharmacists need to increase their knowledge in order to help asthma patients achieve optimal treatment.

Keywords: asthma, pharmacist, pharmacy, knowledge

\section{PENDAHULUAN}

Asma merupakan penyakit pernafasan kronis dengan frekuensi gejala dan tingkat keparahan yang berbeda-beda. Saat ini penderita asma di dunia sebanyak 234 juta jiwa dan diperkirakan akan meningkat setiap tahun (WHO, 2013). Hasil penelitian dari berbagai rumah sakit di seluruh Indonesia menunjukkan prevalensi asma yang berakibat pada kematian sebesar 2,4\% (RISKESDAS, 2018). Kondisi asma yang tidak mendapatkan penanganan seera tepat dapat menyebabkan penurunan kualitas hidup dan produktivitas, peningkatan biaya kesehatan, peningkatan risiko perawatan di rumah sakit dan kematian. Oleh karena itu, manajemen penyakit asma sangat penting untuk mengurangi morbiditas dan mortalitas (Lorensia dan Lisiska, 2011).

Apoteker sebagai pelayanan kefarmasian di apotek, sangat berperan dalam manajemen asma, menilai kontrol asma, merekomendasikan penyesuaian obat atau alat, konseling dalam penggunaan inhaler (Deeks et al. 2018; Williams, 2016). Penelitian Nastaravicius dan Ramanauskiene (2018), melibatkan 21 apotek di Lithuania dan 338 pasien asma menunjukkan bahwa sebelum layanan farmasi disediakan, jumlah rata-rata kesalahan yang dilakukan pasien dalam penggunaan obat asma adalah 2,03; jumlah ini menurun menjadi 1,12 setelah pelayanan kefarmasian oleh apoteker dilakukan.

Hasil penelitian Lim et al. (2012), pada 120 pasien asma di Asia menunjukkan ada perbaikan gejala 
asma dan kepatuhan secara signifikan setelah konseling oleh apoteker selama 6 dan 12 bulan. Penelitian di Yogyakarta pada 75 pasien asma, konseling dapat meningkatkan tingkat kontrol asma dan kepuasan pasien dalam menggunakan inhalasi (Herawati et al., 2013).

Agar dapat melaksanakan pelayanan kefarmasian pada asma secara optimal, apoteker perlu memiliki pengetahuan mengenai pengetahuan terkait pengobatan asma dan cara penggunaan inhaler (Gemicioglu et al., 2014; Khan dan Azhar, 2013). Oleh karena itu, penelitian ini bertujuan mengetahui tingkat pengetahuan pengobatan asma dari apoteker komunitas di Kota Surabaya Timur.

\section{METODE PENELITIAN}

Desain penelitian yang digunakan adalah cross sectional dan pengambilan data dilakukan melalui kuesioner. Variabel yang diamati adalah tingkat pengetahuan pengobatan asma bagi apoteker meliputi 6 domain, yaitu terapi farmakologi, etiologi dan patofisiologi, faktor risiko, definisi, gejala, dan terapi non farmakologi.

Populasi yang digunakan adalah apoteker yang menjalankan praktek kefarmasian di apotek di wilayah Surabaya Timur. Sampel (subjek) yang digunakan adalah apoteker yang bekerja di apotek non franchise di wilayah Surabaya Timur yang memenuhi kriteria seperti: bersedia terlibat dalam penelitian, berkerha di apotek yang menjual sediaan inhaler dan bekerja di apotek (stand by) minimal 8 jam/hari selama 5 hari kerja. Satu apoteker mewakili satu apotek. Teknik sampling yang digunakan adalah purposive sampling.

Besar sampel yang digunakan dalam penelitian ialah minimal 76 orang. Metode perhitungan sampel menggunakan rumus:

$$
n=\frac{Z^{2} x p(1-p)}{d^{2}}
$$

dengan:

n: besar sampel minimal;

$\mathrm{Z}_{1-\alpha / 2}$ : derajat kemaknaan 1,96 (untuk $\alpha=0,05$ );

$\mathrm{p}$ : proporsi variabel yang ingin diteliti; 
Jurnal Ilmiah Ibnu Sina, 5(2), Oktober 2020, 278-287

p-ISSN: 2502-647X; e-ISSN: 2503-1902

d: derajat penyimpangan terhadap populasi yang diinginkan. Dan nilai $\mathrm{p}$ yang digunakan ialah 27,3\%, yang merupakan data penduduk obesitas di Kota Surabaya, Jawa Timur. Jadi $\mathrm{p}=$ 0,273 (Riskesdas, 2013). Maka besar sampel penelitian (n) minimal tiap kelompok penelitian sebesar 76 orang.

Kuesioner yang digunakan berasal dari penelitian sebelumnya (Lorensia et al., 2017) Kuesioner tersebut diterjemahkan dalam bahasa Indonesia kemudian dilakukan validasi bahasa ke dalam Bahasa Indonesia. Selanjutnya pengambilan data dilakukan dengan mendatangi apotek satu per satu untuk menemui perwakilan apoteker dari setiap apotek. Wawancara dilakukan secara langsung dengan subjek penenelitian. Pada penelitian ini analisa data dilakukan deskriptif.

\section{HASIL DAN PEMBAHASAN}

\section{Pelaksanaan Penelitian}

Penelitian dilakukan mulai April sampai Juni 2019. Dari 116 subjek, 108 diantaranya masuk kedalam kriteria inklusi dan 8 subjek lainnya tidak masuk kriteria inklusi.
Hal ini disebabkan 8 subjek tidak menjual berbagai macam inhaler di apotek tempat berpraktek dan tidak berpraktek stand by di apotek minimal 8 jam per hari selama 5 hari. Maka dapat ditentukan besar response rate untuk mengetahui besar tingkat pengembalian dalam penelitian. Dari perhitungan tersebut maka didapatkan response rate sebesar $85,29 \%$.

\section{Uji Validasi dan Reliabilitas Kuesioner}

Penelitian ini menggunakan uji validitas dengan metode pearson correlation yang mengkorelasikan antara skor masing-masing item soal dalam kuesioner dengan skor total yang diperoleh dalam penelitian. Jika ada item soal yang tidak memenuhi syarat maka tersebut tidak dianalisa lebih lanjut. Instrumen penelitian dinyatakan valid apabila nilai t-hitung pearson correlation lebih besar dari ttabel. Nilai t-tabel pada penelitian ini: $\mathrm{n}=108$ (jumlah sampel) dan $\mathrm{a}=0,05$ (nilai signifikan adalah 5\%). Sehingga didapatkan nilai t-tabel = 1,6591 .

Tabel 1 menunjukkan ada 15 soal dari 20 soal yang dinyatakan 
Jurnal Ilmiah Ibnu Sina, 5(2), Oktober 2020, 278-287

p-ISSN: 2502-647X; e-ISSN: 2503-1902

valid (t-hitung $>$ t-tabel) sehingga pertanyaan tersebut dapat dianalisa lebih lanjut. Sedangkan pertanyaan pada butir 4, 7, 8, 12 dan 17 tidak valid (t-hitung $<$ t-tabel) $\quad$ sehingga dieliminasi dari kuesioner penelitian dan tidak dianalisa lebih lanjut.

Tabel 1. Hasil Uji Indeks diskriminasi dengan Pearson

Correlation

\begin{tabular}{cccc}
\hline $\begin{array}{c}\text { No } \\
\text { Soal }\end{array}$ & $\begin{array}{c}\mathbf{N} \\
\text { (jumlah } \\
\text { sampel) }\end{array}$ & $\begin{array}{c}\text { Nilai } \\
\text { Pearson } \\
\text { Correlation }\end{array}$ & $\begin{array}{c}\text { Nilai t- } \\
\text { hitung }\end{array}$ \\
\hline $\mathbf{1}$ & 108 & 0,3930 & 4,4005 \\
$\mathbf{2}$ & 108 & 0,4217 & 4,7880 \\
$\mathbf{3}$ & 108 & 0,4395 & 5,0372 \\
$\mathbf{4} *$ & 108 & 0,0472 & 0,4868 \\
$\mathbf{5}$ & 108 & 0,5682 & 7,1085 \\
$\mathbf{6}$ & 108 & 0,4832 & 5,6825 \\
$\mathbf{7} *$ & 108 & 0,1024 & 1,0604 \\
$\mathbf{8}$ & 108 & $-0,1190$ & $-1,2337$ \\
$\mathbf{9}$ & 108 & 0,3019 & 3,2604 \\
$\mathbf{1 0}$ & 108 & 0,2336 & 2,4737 \\
$\mathbf{1 1}$ & 108 & 0,3104 & 3,3616 \\
$\mathbf{1 2} *$ & 108 & 0,1381 & 1,4359 \\
$\mathbf{1 3}$ & 108 & 0,1629 & 1,6994 \\
$\mathbf{1 4}$ & 108 & 0,2741 & 2,9344 \\
$\mathbf{1 5}$ & 108 & 0,2540 & 2,7039 \\
$\mathbf{1 6}$ & 108 & 0,4357 & 4,9844 \\
$\mathbf{1 7} *$ & 108 & $-0,0639$ & $-0,6594$ \\
$\mathbf{1 8}$ & 108 & 0,2037 & 2,1419 \\
$\mathbf{1 9}$ & 108 & 0,1934 & 2,0290 \\
$\mathbf{2 0}$ & 108 & 0,3955 & 4,4335 \\
\hline Keterangan $*$ *tidakvalid &
\end{tabular}

Sedangkan hasil uji reliabilitas KR20 atau Kuder- Richardson Formula 20. Instrumen dinyatakan reliabel jika nilai KR20 >0,7. Hasil uji reliabilitas menunjukkan nilai KR20 $=0,7414$, sehingga disebut reliabel.

\section{Karakteristik Subjek Penelitian}

Karakteristik subjek berada di Surabaya Timur meliputi kecamatan Gubeng, Gunung Anyar, Sukolilo, Tambaksari, Mulyorejo, Rungkut dan Tenggilis Mejoyo. Didapatkan 108 subjek penelitian terdiri dari 90 subjek perempuan dan 18 subjek lakilaki. Rentang usia subjek yang mengisi kuesioner adalah 22-53 tahun, didominasi dengan usia 22-35 tahun sebanyak 81,48\%.

\section{Tingkat Pengetahuan mengenai} Pengobatan Asma

Tabel 2 menggambarkan jumlah subjek yang menjawab benar. Jawaban benar terbanyak pada pertanyaan kuesioner ada pada nomor soal ke-1 (97,22\%), yaitu mengenai terapi pengobatan asma terdiri controller dan reliever, hampir keseluruhan apoteker memahami terapi asma terdiri dari pengontrol (controller) dan pelega (reliever). Pengetahuan mengenai hal ini sangat penting karena merupakan dasar dari pengobatan asma. Reliever berfungsi mengatasi bronkokonstriksi akut dan 
Jurnal Ilmiah Ibnu Sina, 5(2), Oktober 2020, 278-287

p-ISSN: 2502-647X; e-ISSN: 2503-1902

digunakan hannya bila perlu, berbeda dengan controller yang harus digunakan secara rutin agar tetap terkontrol. Edukasi kepada pasien mengenai pengobatan asma dapat mengurangi penggunaan layanan perawatan kesehatan darurat dan rawat inap, meningkatkan kualitas hidup dan kontrol asma, dan mengurangi pengeluaran perawatan kesehatan pada asma (Bellanti dan Settipane, 2016; Lampkin et al., 2016).

Jawaban benar terkecil pada pertanyaan kuesioner nomor delapan ada pada nomor soal ke-16 (36,11\%), yaitu mengenai gejala asma yang dapat terjadi tiba-tiba. Perburukan asma dapat menyebabkan serangan asma yang dapat timbul akibat adanya trigger (Gautier dan Charpin, 2017).

Dari 108 sampel penelitian nilai jawaban benar terendah (dalam skala 100) adalah 35 yaitu sebanyak 1 subjek, dan total nilai jawaban tertinggi (dalam skala 100) adalah 90 yaitu sebanyak 2 subjek.

Berdasarkan nilai Q1, Q2, Q3 maka nilai $\leq Q_{1}$ menjadi standar tingkat pengetahuan apoteker yang rendah terkait pengobatan asma di farmasi komunitas (Q1=60). Nilai $\mathrm{Q}_{2}$ adalah nilai tengah (median) yang menunjukkan tingkat pengetahuan apoteker pada umunya terkait pengobatan asma di farmasi komunitas (Q2-65). Dan nilai $\geq Q_{3}$ menjadi standar tingkat pengetahuan apoteker yang tinggi terkait pengobatan asma di farmasi komunitas (Q3=75). Maka didapatkan hasil 37 apoteker subjek memiliki tingkat pengetahuan rendah (nilais60), 41 apoteker subjek memiliki tingkat pengetahuan standar, 30 apoteker subjek memiliki tingkat pengetahuan yang tinggi (nilai $\geq 75$ ) mengenai pengobatan asma farmasi komunitas.

\section{Klasifikasi} pertanyaan berdasarkan domain menunjukkan bahwa pertanyaan nomor $1,2,3,5,6$, $8,9,10,15,17,19,20$ memiliki domain yang sama yaitu mengenai terapi farmakologi. Pertanyaan mengenai domain terapi farmakologi memiliki porsi yang besar dalam kuesioner untuk memenuhi harapan kompetensi yang dikuasai apoteker yaitu terutama pada bidang terapi farmakologi. Dalam satu domain terapi farmakologi yang terdiri dari 
Jurnal Ilmiah Ibnu Sina, 5(2), Oktober 2020, 278-287

p-ISSN: 2502-647X; e-ISSN: 2503-1902

12 pertanyaan, diperoleh rata-rata Pada domain terapi non farmakologi, hasil 66,13\%. Pada domain etiologi definisi dan gejala masing-masing dan patofisiologi diperoleh rata-rata diperoleh rata-rata hasil 91,67\%, hasil 63,89\%. Pada domain faktor $87,04 \%$, dan 36,11\% (Tabel 2). risiko diperoleh rata-rata $62,97 \%$.

Tabel 2. Profil Jawaban Soal Pertanyaan Pengetahuan mengenai Pengobatan Asma

\begin{tabular}{|c|c|c|c|c|c|}
\hline \multirow{2}{*}{$\begin{array}{l}\text { No } \\
\text { Soal }\end{array}$} & \multirow{2}{*}{ Pernyataan } & \multirow{2}{*}{$\begin{array}{c}\text { Domain } \\
\text { yang Dituju }\end{array}$} & \multicolumn{2}{|c|}{$\begin{array}{c}\text { Jumlah subjek yang } \\
\text { menjawa benar }\end{array}$} & \multirow{2}{*}{$\begin{array}{l}\text { Nilai } \\
\text { Rerata } \\
\text { Per } \\
\text { Domain }\end{array}$} \\
\hline & & & $\begin{array}{l}\text { Jumlah } \\
\text { subjek }\end{array}$ & $\begin{array}{l}\text { Persentase } \\
\quad(\%)\end{array}$ & \\
\hline \multirow[t]{2}{*}{1} & Agen terapi asma dibagi dalam 2 & Domain & 105 & 97,22 & 77,67 \\
\hline & $\begin{array}{l}\text { kelompok, yaitu pelega (reliever) dan } \\
\text { pengontrol (controller) asma }\end{array}$ & $\begin{array}{l}\text { Terapi } \\
\text { Farmakologi }\end{array}$ & & & \\
\hline 2 & $\begin{array}{l}\text { Peran agen pengontrol dalam terapi asma } \\
\text { adalah menghilangkan rasa sesak pasien } \\
\text { saat terjadi serangan asma }\end{array}$ & & 64 & 59,26 & \\
\hline 3 & $\begin{array}{l}\text { Agen pengontrol hanya digunakan bila } \\
\text { perlu saat serangan asma dialami pasien }\end{array}$ & & 64 & 59,26 & \\
\hline 5 & Candidiasis orofaringeal merupakan efek & Domain & 54 & 50,00 & 50,50 \\
\hline & $\begin{array}{l}\text { samping yang disebabkan oleh } \\
\text { penggunaan inhaler yang mengandung } \\
\text { salbutamol }\end{array}$ & $\begin{array}{l}\text { Etiologi dan } \\
\text { Patofisiologi }\end{array}$ & & & \\
\hline 6 & $\begin{array}{l}\text { Salbutamol digunakan untuk mengontrol } \\
\text { asma }\end{array}$ & & 47 & 43,52 & \\
\hline 9 & $\begin{array}{l}\text { Cara menghirup obat inhaler asma yang } \\
\text { benar adalah melalui hidung }\end{array}$ & $\begin{array}{l}\text { Domain } \\
\text { Faktor }\end{array}$ & 93 & 86,11 & 82,00 \\
\hline 10 & $\begin{array}{l}\text { Aerosol yang mengandung Ipratropium } \\
\text { bromida dapat menyebabkan glaukoma } \\
\text { mengenai mata }\end{array}$ & Risiko & 84 & 77,78 & \\
\hline 11 & $\begin{array}{l}\text { Keparahan asma meningkat bila sekali } \\
\text { terkena serangan asma }\end{array}$ & & 69 & 63,89 & \\
\hline 13 & $\begin{array}{l}\text { Hanya orang dewasa yang dapat sakit } \\
\text { asma }\end{array}$ & $\begin{array}{l}\text { Domain } \\
\text { Definisi }\end{array}$ & 104 & 96,3 & 101,50 \\
\hline 14 & Penderita asma tidak boleh olahraga & & 99 & 91,67 & \\
\hline 15 & $\begin{array}{l}\text { Tidak baik bila pasien asma tidak } \\
\text { menggunakan reliever sama sekali }\end{array}$ & $\begin{array}{l}\text { Domain } \\
\text { Gejala }\end{array}$ & 47 & 43,52 & 43,00 \\
\hline 16 & Asma terjadi karena tiba-tiba & & 39 & 36,11 & \\
\hline 18 & Stress dapat menyebabkan asma & Domain & 87 & 80,56 & 94,00 \\
\hline 19 & $\begin{array}{l}\text { Semakin parah tingkat asma maka } \\
\text { semakin banyak dosis/jenis obat yang } \\
\text { dibutuhkan }\end{array}$ & $\begin{array}{l}\text { Terapi Non } \\
\text { Farmakologi }\end{array}$ & 103 & 95,37 & \\
\hline
\end{tabular}


Jurnal Ilmiah Ibnu Sina, 5(2), Oktober 2020, 278-287

p-ISSN: 2502-647X; e-ISSN: 2503-1902

\begin{tabular}{|c|c|c|c|c|c|}
\hline \multirow{2}{*}{$\begin{array}{l}\text { No } \\
\text { Soal }\end{array}$} & \multirow{2}{*}{ Pernyataan } & \multirow{3}{*}{$\begin{array}{c}\text { Domain } \\
\text { yang Dituju }\end{array}$} & \multicolumn{2}{|c|}{$\begin{array}{l}\text { Jumlah subjek yang } \\
\text { menjawa benar }\end{array}$} & \multirow{3}{*}{$\begin{array}{c}\text { Nilai } \\
\text { Rerata } \\
\text { Per } \\
\text { Domain }\end{array}$} \\
\hline & & & $\begin{array}{c}\text { Jumlah } \\
\text { subjek }\end{array}$ & $\begin{array}{l}\text { Persentase } \\
\quad(\%)\end{array}$ & \\
\hline 20 & $\begin{array}{l}\text { Agonis beta inhaler lebih baik digunakan } \\
\text { dibandingkan oralnya }\end{array}$ & & 92 & 85,19 & \\
\hline
\end{tabular}

Domain farmakologi
mendukung kemampuan apoteker
dalam konseling pengobatan terhadap
pasien masih kurang karena tidak
semua apoteker dapat menjelaskan
setiap tahap pengobatan dengan tepat
dan benar. Hal ini didukung beberapa
penelitian terdahulu yang
menunjukkan bahwa Sebagian besar
apoteker mengalami kesulitan dalam
memberikan penjelasan cara
penggunaan inhaler yang tepat,
seperti MDI (metered=dose inhaler)

(Amelia dan Nathania, 2017), MDI

dengan spacer (Lorensia et al., 2018),

DPI (dry-powder inhaler) seperti

Diskus $^{\circledR}$ dan Turbuhaler ${ }^{\circledR}$ (Lorensia et al., 2016), dan Handihaler ${ }^{\circledR}$ (Lorensia et al., 2019).

Dari pertanyaan kuesioner, domain paling tinggi adalah pada terapi non-farmakologi $(94,00)$. Terapi non farmakologi dapat meliputi intervensi perubahna perilaku pasien, program selfmanagement bagia pasien, pemantauan dan follow-up pengobatan pasien. Penelitian terdahulu oleh Zairina et al. (2014) menunjukkan bahwa intervensi tenaga kesehatan pada terapi nonfarmakologi memberikan perbaikan yang signifikan terhadap control asma.

Sedangkan nilai terendah pada domain gejala $(43,00)$. Padalah gejala asma dapat menjadi parameter monitoring pengobatan asma untuk menilai efektifitas terapi, serta mengetahui lebih dini risiko perburukan asma (Deeks et al., 2018; Lampkin et al., 2016).

Beberapa hal yang mempengaruhi kesulitan dalam konseling pasien yang dialami oleh apoteker salah satunya disebabkan oleh ketersediaan inhaler asma yang minim di apotek. Apotek lebih banyak menjual MDI dibandingkan DPI. Faktor lain yang mempengaruhi adalah akses informasi yang terbatas. Hambatan utama yang ditemui adalah 
Jurnal Ilmiah Ibnu Sina, 5(2), Oktober 2020, 278-287

p-ISSN: 2502-647X; e-ISSN: 2503-1902

tidak adanya alat peraga $(35 \%)$ dan minimnya informasi yang diakses oleh apoteker, seperti: minimnya informasi atau pelatihan yang diperoleh $\quad(25 \%), \quad$ kesulitan mempelajari bermacam variasi inhaler $(23 \%)$, barang jarang terjual $(6 \%)$, belum pernah melihat inhaler $(6 \%)$, brosur tidak jelas (4\%) dan pasien tahu pakai (2\%).

Penelitian terdahulu tingkat pengetahuan apoteker mengenai pengobatan asma juga pernah dilakukan oleh Gemicioglu et al. (2014), pada 26 apoteker dan 261 asisten apoteker di Istanbul menunjukkan tingkat pengetahuan yang masih terbatas mengenai asma dan sediaan inhaler, sehingga membutuhkan pendidikan di kemudian hari. Sedangkan penelitian lain oleh Khan dan Azhar (2013) pada 74 apoteker di Alahsa, Saudi Arabia, menunjukkan bahwa lama bekerja mempengaruhi secara signifikan tingkat pengetahuan cara penggunaan inhaler MDI untuk pengobatan asma.

\section{KESIMPULAN}

Sebagian besar subjek memiliki tingkat pengetahuan asma yang sedang/standar $(37,96 \%)$ dan hanya sebagian kecil yang memiliki tingkat pengetahuan yang tinggi (27,77\%). Dari pertanyaan kuesioner, domain paling tinggi adalah pada terapi nonfarmakologi $(94,00)$ dan nilai terendah pada domain gejala $(43,00)$.

\section{UCAPAN TERIMA KASIH}

Para peneliti mengucapkan terima kasih atas dukungan Hibah LPPM Universitas Surabaya.

\section{DAFTAR PUSTAKA}

Bellanti, J.A., Settipane, R.A. (2018). 'Relievers, controllers, and inhaler technique: A physicianpatient challenge', Allergy Asthma Proc, 37(5):347-349.

Deeks, L.S., Kosari, S., Boom, K., et al. (2018). 'The Role of Pharmacists in General Practice in Asthma Management: A Pilot Study', Pharmacy (Basel)., 6(4),pp.114.

Gautier, C., Charpin, D. (2017). 'Environmental triggers and avoidance in the management of asthma', J Asthma Allergy, 10,pp.47-56.

Gemicioglu, B., Borekci, S., Can, G. (2014). 'Investigation of knowledge of asthma and inhaler devices in pharmacy workers', $J$ Asthma, 51(9),pp.982-8. 
Jurnal Ilmiah Ibnu Sina, 5(2), Oktober 2020, 278-287

p-ISSN: 2502-647X; e-ISSN: 2503-1902

Herawati, M., Hakim, L., Pramantara, I.D.P. (2013). 'Pharmacist's Counselling Effects on Asthma Control Level and Satisfaction with Inhaled Asthma Treatment for Asthma Patient Undergoing Outpatient Care', Jurnal Manajemen dan Pelayanan Farmasi, 3(4),pp.273-82.

Khan, T.M., Azhar, S. (2013). 'A study investigating the community pharmacist knowledge about the appropriate use of inhaler, Eastern Region AlAhsa, Saudi Arabia', Saudi Pharmaceutical Journal, 21(2),pp.153-7.

Lampkin, S.J., Maslouski, C.A., Maish, W.A., John, B.M. (2016). 'Asthma Review for Pharmacists Providing Asthma Education'.J Pediatr Pharmacol Ther. 21(5),pp.:444-71.

Lim, T., Kowalski, S., Tan, K. (2012). 'Impact of Asthma Counseling by Pharmacist on Asthma Control and Medication Adherence in Asia', The Journal of Allergy and Clinical Immunology, 129(2),pp.AB125.

Lorensia, A., Lisiska, N. (2011). 'Illness Perceptions Study of Asthma Treatment Compliance in Pharmaceutical Care', ANIMA, 26(3),pp.184-8.

Lorensia, A., Nathania, J. (2017). 'Studi Kelengkapan Penjelasan Informasi Cara Penggunaan Controller Metered-Dose Inhaler (MDI) yang Mengandung Kortikosteroid sebagai Terapi Asma di Apotek Kabupaten Tuban', Jurnal Ilmiah Manuntung, 3(1),pp.14-25.
Lorensia, A., Queljoe, D.D., Karina, B.L., Hewu, A. (2016). 'Studi Kelengkapan Penjelasan Cara Penggunaan Sediaan Controller Inhaler (Kombinasi Kortikosteroid Dengan Beta-2 Agonis) Jenis Diskus ${ }^{\circledR}$ Dan Turbuhaler ${ }^{\circledR}$ Oleh Apoteker Di Apotek', Jurnal Ilmiah Manuntung, 2(2),pp.137-146.

Lorensia, A., Queljoe, D.D., Tandjung, Y.C.W. (2019). 'Profil Kelengkapan Informasi oleh Apoteker Tentang Cara Penggunaan Sediaan Handihaler $^{\circledR}$ yang Mengandung Tiotropium Bromida di Apotek Wilayah Surabaya Timur', Jurnal Sains dan Kesehatan, 2(1),pp.2539.

Lorensia, A., Queljoe, D.D., Valensia, Y. (2018). 'Karakteristik Informasi Terkait Cara Penggunaan Metered-Dose Inhaler dengan Spacer yang Mengandung Kombinasi Beta-2 Agonis dan Kortikosteroid oleh Apoteker di Apotek Wilayah Surabaya Timur'. Jurnal Ilmiah Manuntung, 4(1):15-27.

Lorensia, A., Setiawan, B., Maranatha, D., Yudiarso, A. (2017). 'Effectiveness of Education Based InformationMotivation-Behavioral Skill (IMB) Model of Improving Knowledge, Motivation, and Performance Demonstration Metered-Dose Inhaler (MDI) to Community Pharmacists in Surabaya', International Journal of Pharmaceutical and Clinical Research, 9(7),pp.485-495. 
Jurnal Ilmiah Ibnu Sina, 5(2), Oktober 2020, 278-287

p-ISSN: 2502-647X; e-ISSN: 2503-1902

Nastaravicius, A., Ramanauskiene, K.

(2018). 'Role of a Community

Pharmacy Service in Care of

Bronchial Asthma Patients in

Lithuania', Canadian

Respiratory Journal, 6060581.

Riset Kesehatan Dasar (Riskesdas). (2018) 'Badan penelitian dan pengembangan kesehatan kementerian kesehatan RI'.

WHO. (2013). Global surveillance, prevention and control of chronic respiratory diseases. Geneva: WHO.

Williams, R.A. (2016). 'Pharmacists' role is key in asthma management, inhaler technique,, Pharmacy Today, 22(11):26-7.

Zairina, E., Stewart, K., Abramson, M.J., George, J. (2014). 'The effectiveness of nonpharmacological healthcare interventions for asthma management during pregnancy: a systematic review', BMC Pulmonary Medicine, 14(46),pp.1-8. 


\section{Jurnal Ilmiah Ibnu Sina}

\section{Archives

\section{Author Fees}

2020-02-19

Starting with the publication of Volume 5 Number 1 March 2020, Jurnal Ilmiah Ibnu Sina determined Article Processing Charges (APCs) for each article published to be Rp. 500,000.00. The payment bill is done at the same time as sending a Letter of Acceptance (LoA) after the article has passed through a peer-reviewed process and is ready

to be published. Read More >

\section{Current Issue}

Vol 5 No 2 (2020)

Published: 2020-10-27 


\section{Artikel}

OPTIMASI PRODUKSI ANTIBAKTERI CAIRAN KULTUR ISOLAT BAKTERI (ISOLAT TE234) TERHADAP BAKTERI Escherichia coli DAN Staphylococcus aureus

Sandi Kurniawan, Alfian Syarifuddin, Herma Fanani Agusta, Missya Putri Kurnia Pradani

$\triangle$ PDF (Bahasa Indonesia)

FORMULASI GRANUL EFFERVESCENT EKSTRAK ETANOL 90\% BUAH LABU AIR (Lagenaria siceraria) SEBAGAI ANTIOKSIDAN DENGAN VARIASI GAS GENERATING AGENT

Dyera Forestryana, Yunitha Hestiarini, Aristha Novyra Putri

$220-229$

ه PDF (Bahasa Indonesia)

\section{TINGKAT PENGETAHUAN PASIEN TENTANG EFEK SAMPING OBAT CAPTOPRIL DAN AMLODIPIN DI} PUSKESMAS SUNGAI JINGAH

Novia Ariani, Dwi Rizki Febrianti, Rakhmadhan Niah

目 PDF (Bahasa Indonesia)

PENGARUH PEMBERIAN PELAYANAN INFORMASI OBAT DAN KONSELING TERHADAP TINGKAT KEPATUHAN MINUM OBAT PADA PASIEN DIABETES MELITUS DENGAN HIPERTENSI DI RUMAH SAKIT DAERAH IDAMAN BANJARBARU

Satrio Wibowo Rahmatullah, Ika Maulida Nurrahma, Adnan Syahrizal

쇼 PDF (Bahasa Indonesia)

UJI AKTIVITAS ANTIOKSIDAN FRAKSI N-HEKSAN DAUN AFRIKA (Vernonia amygdalina Del.) DENGAN METODE DPPH

Nurul Fatimah, Reksi Sundu 
POTENSI HIPOGLIKEMIA DAN HIPERGLIKEMIA PADA PASIEN DIABETES MELITUS TIPE 2 AKIBAT INTERAKSI OBAT

Yardi Saibi, Delina Hasan, Bukhoriah Safitri, Vidia Arlaini Anwar

$\Delta \mathrm{PDF}$ (Bahasa Indonesia)

EVALUASI RASIONALITAS PENGGUNAAN DAN PEMBERIAN OBAT PADA PASIEN HIPERTENSI GERIATRI DI PUSKESMAS TAJINAN PERIODE JANUARI - DESEMBER 2019

Luluk Anisyah, Wibowo Wibowo

$\triangle$ PDF (Bahasa Indonesia)

\section{TINGKAT PENGETAHUAN APOTEKER KOMUNITAS MENGENAI PENGOBATAN ASMA}

Amelia Lorensia, Rifaatul Laila Mahmudah, Leonardo Immanuel

因 PDF (Bahasa Indonesia)

PENGARUH PEMBERIAN EKSTRAK ETANOL DAUN BAWANG DAYAK (Eleutherine Palmifolia L. Merr) TERHADAP KADAR GULA DARAH MENCIT PUTIH (Mus muscullus) YANG DIINDUKSI GLUKOSA

Eka Kumalasari, Syifa Maharani, Aditya Maulana Perdana Putra

ه PDF (Bahasa Indonesia)

UJI AKTIVITAS ANTIBAKTERI KOMBINASI EKSTRAK DAUN SIRIH DAN BIJI PINANG SERTA GAMBIR TERHADAP Streptococcus mutans

Munira Munira, Galuh Trioktafiani, Muhammad Nasir

图 PDF (Bahasa Indonesia) 
TERATOGENIK EKSTRAK ETANOL UWI BANGGAI UNGU (Dioscorea alata L.) PADA MENCIT BETINA (Mus musculus)

Ihwan Ihwan, Rahmatia Rahmatia, Khildah Khaerati

因 PDF (Bahasa Indonesia)

PENGARUH PEMBERIAN KOMBINASI EKSTRAK BUAH MENGKUDU (Morinda citrifolia L.) DAN KUNYIT (Curcuma longa) TERHADAP HISTOPATOLOGI GINJAL TIKUS WISTAR YANG DIINDUKSI ALLOXAN

Pelastri Rahayu, Retno Hestiningsih, Martini Martini, Dwi Sutiningsih

쇼 PDF (Bahasa Indonesia)

PROFIL KERACUNAN PADA ANAK DI INSTALASI GAWAT DARURAT RUMAH SAKIT TERSIER YOGYAKARTA

Ndaru Setyaningrum, Suci Febriani

쇼 PDF (Bahasa Indonesia)

PENILAIAN DATA AWAL PENERAPAN BRIEF CONSELING FARMASIS DALAM PENINGKATAN PERILAKU, KEPATUHAN MINUM OBAT, HASIL TERAPI DAN KUALITAS HIDUP PASIEN HIPERTENSI DI RSUD ULIN BANJARMASIN

Saftia Aryzki, Amaliyah Wahyuni

国 PDF (Bahasa Indonesia)

\section{INTERVENSI PHARMACY COACHING OLEH MAHASISWA FARMASI UNTUK PERBAIKAN TINGKAT} KEPARAHAN ADIKSI PADA PASIEN NAPZA RAWAT JALAN

Alexxander Alexxander, Ika Puspitasari, Susi Ari Kristina, Cecep Sugeng Kristanto

园 PDF (Bahasa Indonesia) 
UJI AKTIVITAS ANALGETIK EKSTRAK ETANOL HERBA SEMBUKAN (Paederia foetida L.) PADA MENCIT PUTIH JANTAN (Mus musculus) YANG DIINDUKSI DENGAN ASAM ASETAT

Triswanto Sentat, Fitri Handayani

因 PDF (Bahasa Indonesia)

REVIEW : KARAKTERISTIK FISIK DAN DAYA IRITASI MINYAK ATSIRI BUNGA CENGKEH (Syzygium aromaticum) DALAM BEBERAPA TIPE BASIS SEBAGAI ANTI-INFLAMASI

Amraini Amelia, Nining Sugihartini, Hari Susanti

因 PDF (Bahasa Indonesia)

UJI DAYA HAMBAT ANTIBAKTERI SALEP EKSTRAK ETANOL DAUN PANDAN HUTAN (Freycinetia sessiliflora Rizki.) TERHADAP PERTUMBUHAN BAKTERI Staphylococcus epidermidis

UJI DAYA HAMBAT ANTIBAKTERI SALEP EKSTRAK ETANOL DAUN PANDAN HUTAN (Freycinetia sessiliflora Rizki.) TERHADAP PERTUMBUHAN BAKTERI Staphylococcus epidermidis

Fitri Sri Rizki, Ade Ferdinan

因 PDF (Bahasa Indonesia)

UJI AKTIVITAS ANTIOKSIDAN EKSTRAK GANGGANG HIJAU (UIva lactuca L.) DENGAN VARIASI KONSENTRASI PELARUT ETANOL 60\%, 75\%, DAN 96\% MENGGUNAKAN METODE DPPH (1,1-difenil2-pikrilhidrazil)

Desti Kameliani, Nina Salamah, Any Guntarti

因 PDF (Bahasa Indonesia)

PENGGUNAAN METODE BRIEF COUNSELING UNTUK MENINGKATKAN KEPATUHAN MINUM OBAT DAN KEBERHASILAN TERAPI PASIEN HIPERTENSI DI APOTEK KHANZA FARMA GAMBUT

Muhammad Reza Fahlevi, Aulia Rahim 
COST OF ILLNESS PADA PASIEN PENYAKIT KANKER PAYUDARA DI RSUD ULIN BANJARMASIN

Noor Aisyah, Shela Puji Dina

㘣 PDF (Bahasa Indonesia)

KARAKTERISASI PARAMETER SPESIFIK DAN PARAMETER NON SPESIFIK AKAR KUNING (Fibraurea tinctoria)

Supomo Supomo, Hayatus Sa`adah, Eka Siswanto Symasul, Kintoko Kintoko, Hardi Astuti

$416-425$ Witasari

因 PDF (Bahasa Indonesia)

View All Issues

\section{KEBIJAKAN EDITOR:}

1. Naskah yang akan diterbitkan harus sudah disubmit via ojs (bukan via email) paling lambat 2 bulan sebelum jadwal penerbitan (maksimal Januari untuk terbitan Maret, dan Agustus untuk terbitan Oktober).

2. Jika sebelum deadline 2 bulan tersebut kuota artikel untuk satu terbitan telah terpenuhi (maksimal 25 artikel per terbitan), maka naskah yang masuk berikutnya akan dipertimbangkan untuk direview pada terbitan selanjutnya.

3. Prioritas naskah yang diterbitkan dipertimbangkan berdasarkan urutan submit, kebaruan penelitian, kecepatan revisi dan pembayaran, serta distribusi institusi dan wilayah asal penulis.

4. Jika terdapat 2 atau lebih naskah yang dikirimkan oleh penulis yang sama (baik itu sebagai penulis pertama maupun penulis berikutnya), maka hanya salah satu naskah yang akan masuk ke tahap review.

5. Penulis diharapkan memantau status artikel via web dan mengecek inbox/spam email secara reguler jika artikel telah masuk tahap review.

6. Silakan masukkan alamat lengkap dan nomor ponsel pada Bio Statement di bagian profil untuk memudahkan komunikasi dan distribusi pengiriman naskah cetak. 


\section{ACCREDITATION}

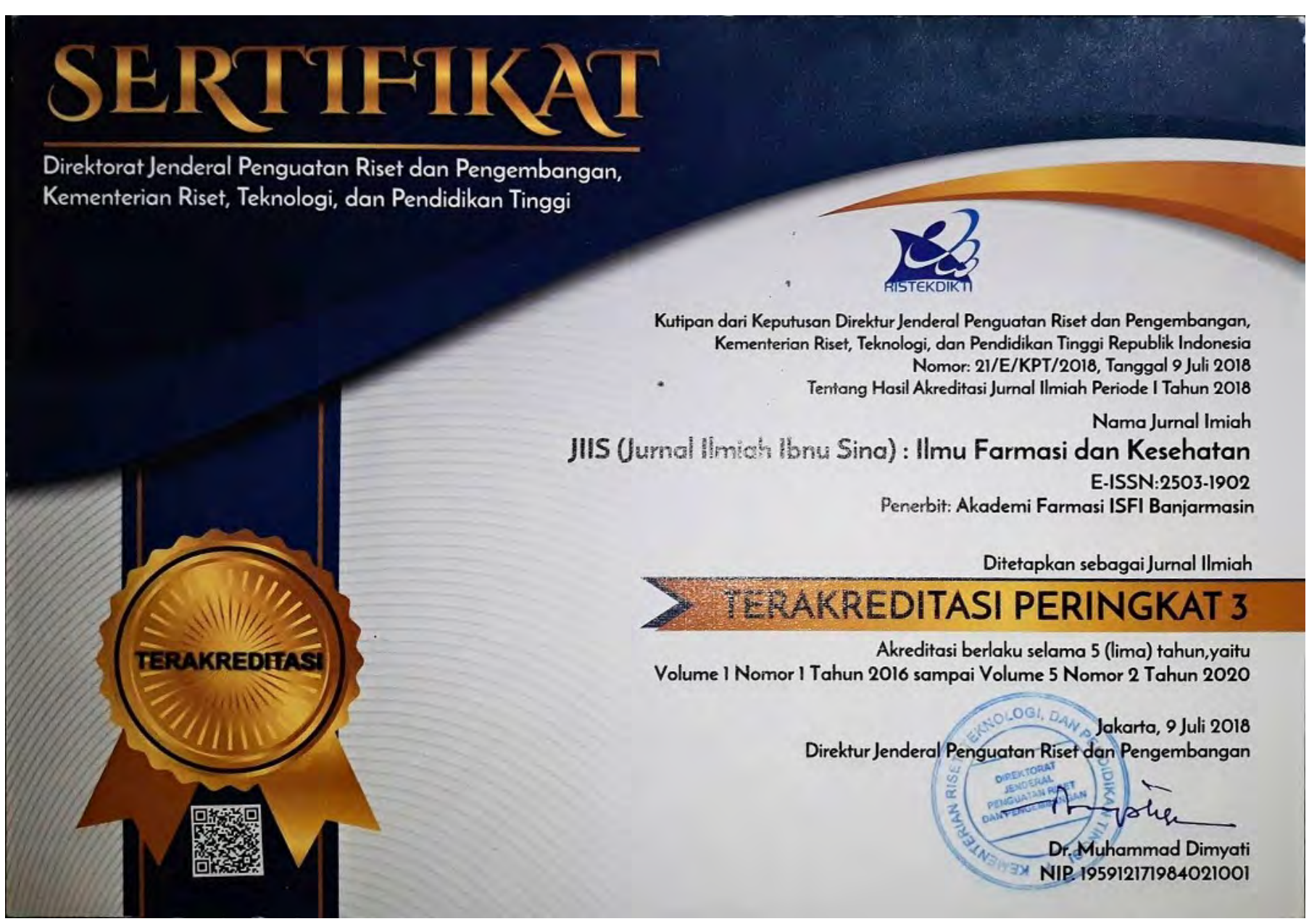

VISITOR 


\section{Visitors}

ID 52,482 ETL 69

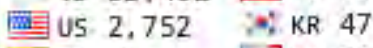

IN 134 IJFR 38

国MY 108 NL 36

品 5 G 92 政A 35

Pageviews: 94,240

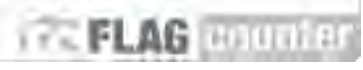

View My Stats

Make a Submission

JOURNAL TEMPLATE

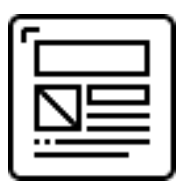

TOOLS

$$
\text { Checker }
$$

grammarly

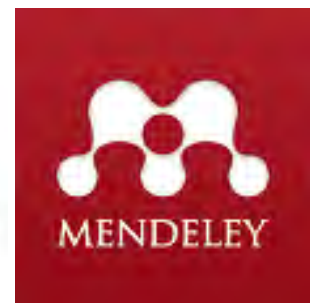


INDEXED BY:

\section{Google}

BASE

Donesearch

Cisinta

A GARUDA

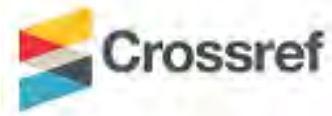

: CiteFactor

p-ISSN: 2502-647X; e-ISSN: 2503-1902

Redaksi Jurnal Ilmiah Ibnu Sina

$\underline{\text { Akademi Farmasi ISFI Banjarmasin }}$ 


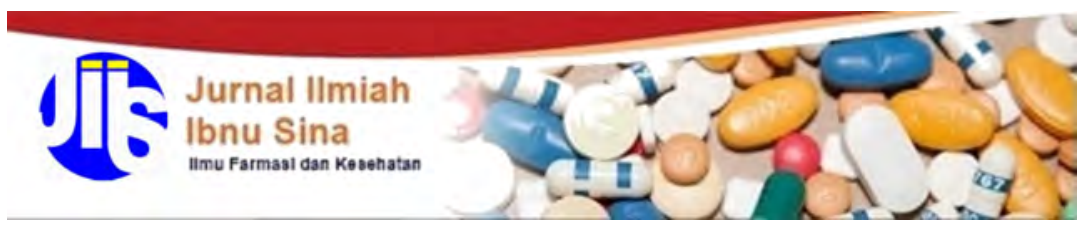

Archives Announcements Editorial Team Submissions About

Search

Home / Editorial Team

REVIEWER

Prof. Dr. Suwijiyo Pramono, DEA., Apt (Universitas Gadjah Mada)

Prof. Dr. Zullies Ikawati, Apt $\underline{\text { t }}$ (Universitas Gadjah Mada)

Prof. Agung Endro Nugroho, M.Si., Ph.D., Apt (Universitas Gadjah Mada)

Prof. Abdul Rohman, M.Si., Ph.D., Apt (Universitas Gadjah Mada)

Prof. Dr. Dyah Aryani Perwitasari, M.Si., Ph.D., Apt (Universitas Ahmad Dahlan)

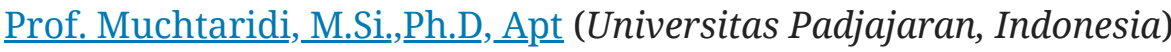

Prof. Dr. Gemini Alam, M.Si.,_Apt. (Universitas Hasanuddin, Indonesia) 
Dr. Brahmaputra Marjadi, MPH., Ph.D. (Western Sydney University)

Dr. AP. Moch Fadli Asmani (Management and Science University, Malaysia)

Dr. rer. nat. Endang Darmawan, Apt (Universitas Ahmad Dahlan)

\section{EDITOR}

Siska Musiam, S.Si., M.Si. (Akademi Farmasi ISFI Banjarmasin)

Riza Alfian, S.Farm., M.Sc., Apt (Akademi Farmasi ISFI Banjarmasin)

Mochammad Maulidie Alfiannor Saputera, M.Farm., Apt (Akademi Farmasi ISFI Banjarmasin)

Dwi Rizki Febrianti, M.Farm.,소t (Akademi Farmasi ISFI Banjarmasin)

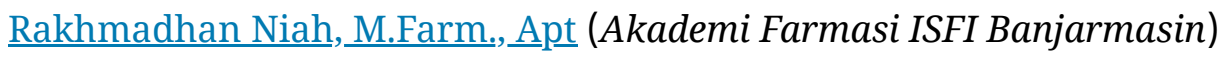

Eka Kumalasari,_M.Farm.,_Apt (Akademi Farmasi ISFI Banjarmasin)

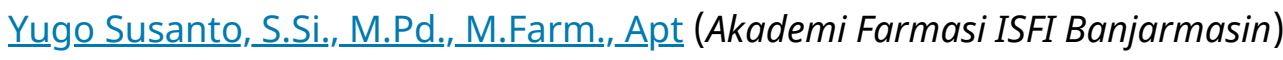

\section{ACCREDITATION}




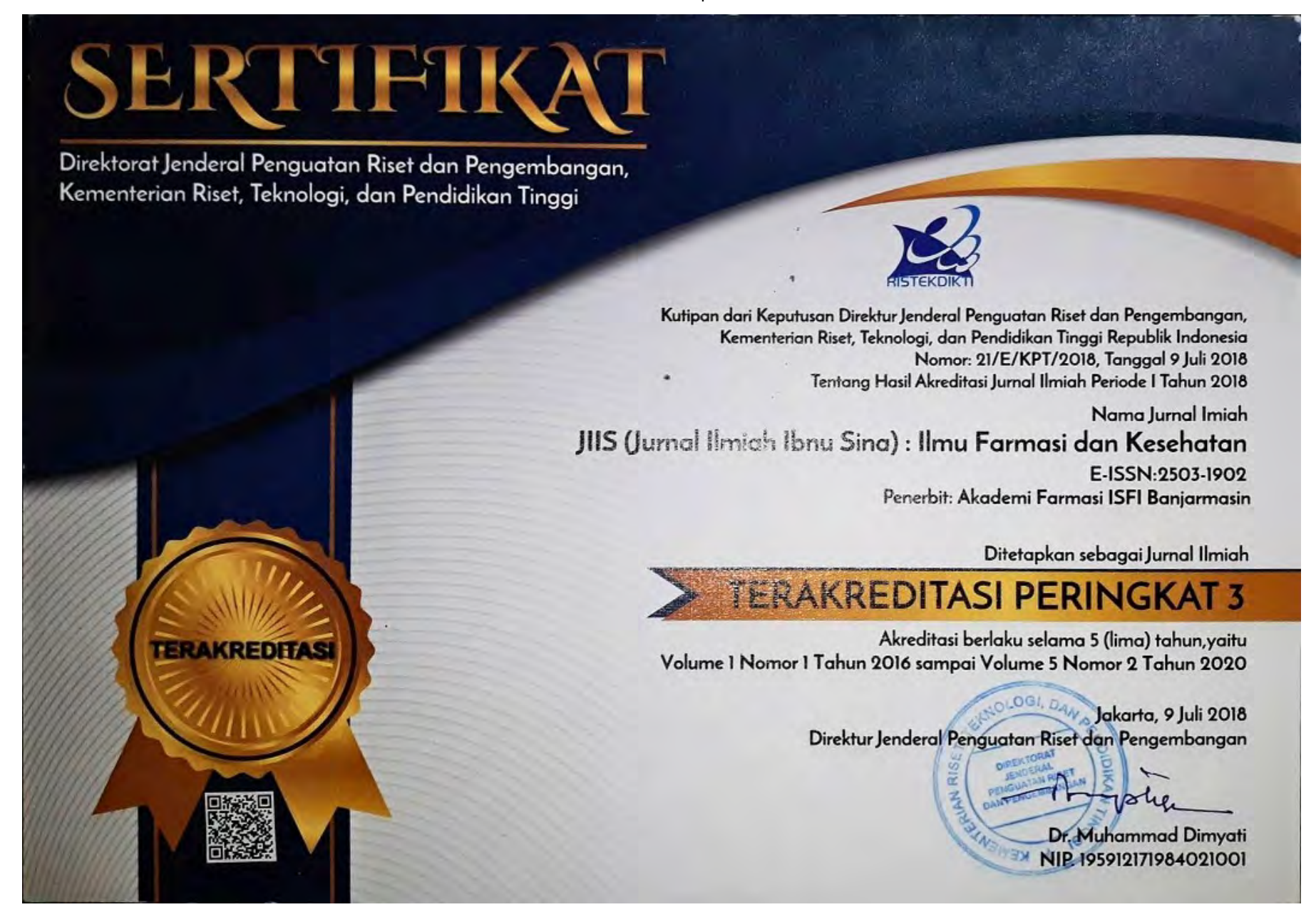

VISITOR 


\section{Visitors}

ID 52,482 TL 69

渵 US 2,752 , KR 47

IN $134 \quad \square F R$

国 MY 108 NL 36

DG 92 政 35

Pageviews: 94,240

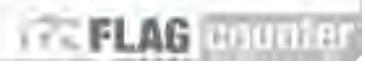

View My Stats

Make a Submission

JOURNAL TEMPLATE

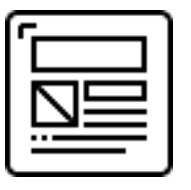

TOOLS

$$
\text { Checker }
$$

grammarly

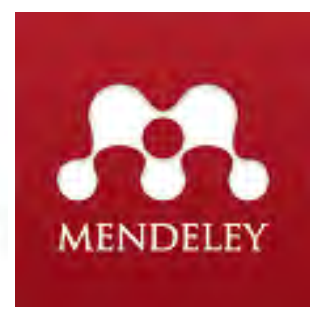


INDEXED BY:

\section{Google}

BASE

Sonesearch

\section{Cîinta}

\section{A GARUDA}

\section{Crossref}

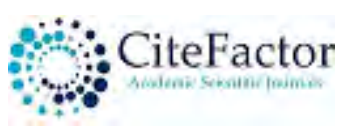

p-ISSN: 2502-647X; e-ISSN: 2503-1902

Redaksi Jurnal Ilmiah Ibnu Sina

Akademi Farmasi ISFI Banjarmasin 
Jl. Flamboyan III/7b Kayu Tangi 70123

Banjarmasin Kalimantan Selatan

Telepon: (0511)-3301610, 3300221

Email: jiis@akfar-isfibjm.ac.id

Copyright (c) Jurnal Ilmiah Ibnu Sina

\section{(c) (†) (?)}

This work is licensed under a Creative Commons Attribution-ShareAlike 4.0 International License.

\section{Platform \& workflow by OJS / PKP}


Jl. Flamboyan III/7b Kayu Tangi 70123

Banjarmasin Kalimantan Selatan

Telepon: (0511)-3301610, 3300221

Email: jiis@akfar-isfibjm.ac.id

Copyright (c) Jurnal Ilmiah Ibnu Sina

\section{(c) (†) (?)}

This work is licensed under a Creative Commons Attribution-ShareAlike 4.0 International License.

Platform \& workflow by

OJS / PKP 